Mini Review

\title{
HEALTHY ALTERNATIVES OF THE MEDITERRANEAN DIET IN LATVIA
}

\author{
Andrejs Ërglis*, Iveta Mintāle*, and Anete Dinne** \\ * Latvian Centre of Cardiology, Pauls Stradinš Clinical University Hospital, Rīga, LV-1002, LATVIA; \\ iveta.mintale@gmail.com \\ ** University of Gastronomic Sciences, Bra, 12042, ITALY \\ Contributed by Andrejs Ërglis
}

The milestone of illness prophylaxis is a healthy lifestyle, which is composed of regular physical activity and a healthy diet. Following the Mediterranean diet for two years has been shown to have significant decrease in cardiovascular death by $9 \%$, cancer by $6 \%$, Parkinson's and Alzheimer's by $13 \%$. This diet helps to control the perfect weight, improves lipid profile and diminishes the risk of diabetes. The Mediterranean diet consists of extra virgin olive oil, vegetables and fruit, wholegrain products, legumes, nuts and seeds, dairy products (with no other sources of fat other than milk fat), fish (at least twice a week), poultry, veal, pork in limited amount, and eggs 0-4 per week. It is possible to adapt this kind of alimentation in the Nordic countries, but it is important to find products grown there with similar nutritional characteristics. Nowadays, fresh fruits and vegetables can be bought all year round, but it is essential to use seasonal products. In Latvia, at this point, attention should be brought to more efficient storage and conservation. We have a vast variety of legumes and cereals. The selection of dairy products should be bigger and of higher quality, because you rarely see local cheeses made in an artisanal manner at the marketplaces. There is good availability of saltwater fish in the cities, but in the countryside the only fish one can buy is salted and smoked, having exaggeratedly high amounts of salt. Consumption of meat and its products should be lowered to a maximum of three times per week. A special attention should be brought to game (such as deer), because it contains low levels of cholesterol and higher amounts of unsaturated fatty acids due to the alimentation of wild herbs. Unfortunately, there is a lack of good quality oil in Latvia, because no other product can be compared to the nutritious components of extra virgin olive oil and its effects on cardiovascular health. Consumption of high amounts of olive oil decreases the incidence of stroke by $41 \%$. Education should be conducted widely to promote tradition and gastronomic heritage as a cultural aspect. Healthy lifestyle has to be visible to everyone at any time as a constant reminder of its importance.

Key words: cardiovascular disease prevention, healthy lifestyle, Mediterranean diet.

\section{INTRODUCTION}

It is known worldwide nowadays that the most frequent cause of death is cardiovascular disease (CVD); about 4.3 million deaths in Europe annually (de Lorgeril et al., 1999). In Latvia the incidence is among the highest in Europe, for men in particular, being more than 130 deaths in 100000 people and 20 to 50 for women (Anonymous, 2006). Many uncontrollable factors influence the formation of CVD, such as age, genetics, race, but the primary cause of CVD is unhealthy lifestyle, such as bad diet, visceral obesity, smoking, little or no physical activity, which are all modifiable aspects for preventing the risk.

\section{HEALTH BENEFITS AND CULTURAL IMPORTANCE OF THE MEDITERRANEAN DIET}

After industrialisation, many refined foods have become available, industrial farming with substances of chemical synthesis has spread widely and physical activity for people has decreased significantly with the availability of transportation and sedentary work, encouraging an unhealthy lifestyle. People often complain about lack of time to prepare meals at home, meaning that sausages, sandwiches or frozen dumplings are their first choice. The problem here is not so much the little free time, but the insignificant value given to food. Considering eating as something important and cultural makes you organise your daily life more efficiently in order to be able to dedicate time for a meal. The Mediterranean way of life is a great example where food still today has great importance.

Since 2010, the Mediterranean diet has been inscribed for the UNESCO Representative List of the Intangible Cultural Heritage of Humanity. Based on century old traditions of Spain, Italy, Morocco and Greece, it has become very popular in the whole world and has been considered as one of the healthiest diets to follow. 
Latvia is one of the few countries left in Europe that still has a good concentration of small non-intensive farms, large areas covered with forests, many rivers and lakes, and the longest part of the boarder has access to the sea. We have a great potential for obtaining high quality products. This fact confirms the possibility to adapt a diet as healthy as the Mediterranean also in Latvia.

The Mediterranean diet "is a set of traditional practices, knowledge and skills passed on from generation to generation and providing a sense of belonging and continuity to the concerned communities." (UNESCO)

The climate of the Mediterranean Sea is very favourable for cultivation of grains, vegetables, fruit and most importantly the olive tree. It is essential to keep in mind that when we talk about the Mediterranean diet, we must consider not only what foodstuffs are used. It is a whole culture of techniques of production, conservation, preservation and conviviality, meaning time, place and people whom to share a meal with (Fundación Dieta Mediterránea). A part of the diet still remains touched only a little by the industrialisation.

As mentioned before, the Mediterranean diet is based mainly on wholegrain products (bread, pasta, couscous), extra virgin olive oil, vegetables and fruit. Fish and meat are consumed in a moderate amount and meals are accompanied by wine or herbal infusions. A lot of condiments and spices are used, which means that salt is added in limited quantities, because spices exalt the salty taste.

People tend to cook a lot at home even now when everything is readily available at the supermarket, so refined foods and carbonated soft drinks are not the first choice.

FOOD CATEGORIES LOOKED AT CLOSER. MEDITERRANEAN DIET AND LATVIAN ALTERNATIVES

Wholegrain products - rich in fibre, improve digestion and have a low glycemic index. Bread is mostly made from unrefined stone-milled flour. Pasta in Italy is consumed "al dente", digested slower than fully cooked pasta, letting the glucose levels in blood rise slowly. Rice is more healthy when consumed unrefined. Complex carbohydrates are the major part of the Mediterranean diet. Wholegrain category of foodstuffs is essential for patients with diabetes.

Cereals - wheat, rye and oats historically are the main cultivated plants in Latvia, so this category of diet is fully available locally.

Fruit and vegetables - full of vitamins, fiber, and phytonutrients. High consumption of tomatoes containing lycopene has been proved a good antioxidant. Cruciferous plants, like cabbages, broccoli, horseradish and other vegetables containing sulfurous compounds are anti-cancerogenic and some can be conserved for wintertime. Consumption of different vegetables and fruits should be a part of each meal.
Since the summer period is very short in Latvia, vegetable preserves can be made. More care should be brought to conservation of fresh produce. It is essential not to forget that salt is necessary only in the right amount for conservation.

Latvia has a wide variety of berries, which are excellent for summertime, like blackberries, cranberries, wild strawberries and raspberries. For winter, apples are a good choice if conserved properly. People who have a garden very often throw away the fruit that they are not able to consume until the end of summer. Instead of wasting a perfectly good product, juices and jams with low sugar content can be made, with low $\mathrm{pH}$ to keep them well preserved.

Greens and legumes. In the Mediterranean region a lot of salad is consumed, which contains bitter compounds of different chemical compositions that work as nutraceuticals. Chicory is a good example of bitter greens. The bigger the variety of green leafed plants consumed, the more the chance to consume enough microelements to improve one's health. Rockets, that can be bought at the market or grown in one's garden, have a tingling property that is due to an anti-cancerogenic compound. Spinach is a good source of iron.

Sometimes when a Latvian is asked, how often he consumes legumes, the response is: "At Christmas as the traditional dish of marble peas with bacon." Since one's daily diet should consist of $50 \%$ carbohydrates, legumes are the perfect source to substitute potatoes or rice. The variety is big - peas, chickpeas, different kinds of lentils, different kinds of beans.

Legumes are rich in soluble and insoluble fibre, they help digestion and are great for intestinal microbiota.

Lipids. High consumption of extra virgin olive oil rich in monounsaturated fatty acids and tocopherol fights free radicals and raises low-density cholesterol in blood. Little or no consumption of butter and no consumption of margarine is needed, as is sweet pastry and bread usually made with olive oil or butter, not margarine or tropical fruit oils.

There are many possible choices for oils in Latvia, such as linseed, sunflower, rapeseed oil, but most of them are refined, meaning that all the possible beneficial vitamins are long gone, but the high quality ones are expensive. It has been shown in many studies that extra virgin olive oil is the best, so this is one of the few products that only with difficulty can be replaced with anything else. Cold pressed extra virgin olive oil should be used for cooking and for fresh consumption, not plain olive oil that contains refined oil.

Dairy. Low consumption of milk and fatty cheese, moderate consumption of yoghurt and other fermented milk products is recommended.

Yoghurt in Greece is a very important part of breakfast served with honey, nuts and fruit making it a wholesome breakfast. 
In Latvia people consume fatty milk products - sour cream, full fat cheese, butter, cottage cheese.

Sour cream is used widely, even in soups. Kefir, however, is an excellent fermented milk product even for lactose intolerant people, because during fermentation all the lactose is consumed by bacteria and it has a significantly lower fat content than sour cream.

Spices and herbs. Adding more spices and herbs to a dish, like mint, basil, thyme, rosemary, makes it tastier and reduces the need for excessive salt. They also contain phytonutrients that can improve one's health. Chili, for example, contains capsaicin that has been seen to reduce inflammation. Rosemary is exceptionally rich in salicylic acid, which is the active compound of aspirin. Many patients suffering from heart disease are prescribed aspirin as an anti-inflammatory drug. Garlic and onions contain sulfurous compounds that lower blood pressure.

The above mentioned plants are used a lot in Latvia for any preparation.

Salt. Salt is used while cooking to season food, as elsewhere in the world, but the Mediterranean people consume less processed foods full of hidden salt that is the main worry for high blood pressure. The addition of pepper or chili makes the taste receptors more sensitive to salty taste, therefore less salt is needed.

Unfortunately, consumption of processed foods in Latvia is quite high, meaning that consumption of excessive salt is inevitable. One in ten males in Latvia add salt to their dish even before tasting it.

Wine. Moderate amounts of red wine is a good source of polyphenols (resveratrol). These antioxidants are found in the skin of red grapes, so white wine does not have the same characteristics. As the French paradox tells us, red wine is good for the cardiovascular system, but it is important to remember that wine is used during healthy meals not in excessive doses - products taken out of their context may not have the same desirable effect.

It is difficult to substitute wine with any other product available in Latvia, even though there are some people who are trying to produce it in cooler climates. White grapes definitely grow better more in the north than red, but polyphenols are found only in the skin of red grapes.

High quality beer could have some similar benefits as wine because of the presence of hop which has bitter compounds that work as an antibacterial. "High quality" should be underlined, meaning non-industrial beer with no extra additives and preservatives. No beer made from corn. Always keep in mind, that consumption of alcohol is not to be encouraged and should be done in moderation.

Fish. In Latvia very little fish is consumed, even though there is a variety of salt and sweet water species.
There is good availability of saltwater fish in the cities, but in the countryside the only fish one can buy is salted and smoked, having inappropriately high amounts of salt (Anonymous, 2008).

In the Mediterranean diet the small fish such as anchovies and sardines are widely used. Many small fish are also available in Latvia and they can substitute them. They have a short maturation period, so they are more sustainable than tuna and salmon, and they are very rich in Omega-3 fatty acids, one of the main reasons for fish consumption. Since they have a short life cycle, they are less polluted with heavy metals.

Sweet water fish is not as rich in Omega-3 as salt water fish; this depends mostly on the habitat it has lived in and on its alimentation. Still it is a good protein source as an alternative to meat.

Meat. Consumption of meat and its products should be lowered to a maximum of three times per week.

Latvians consume too much pork in the form of processed meat. The positive aspect of meat consumption is that recently game is becoming more and more popular.

Game is shown to be very low in fat and cholesterol, high in iron and unsaturated fatty acids, making it a great healthier choice. The composition of meat depends on the animal's diet. Wild animals feed on everything they find in the forests, which could be anything from lichens to berries. This is the reason for the high level of unsaturated fatty acids, if compared to a farm animal fed with corn silage and soy. Physical activity for animals living in the wild increases the amount of iron present in the meat.

It is true that game usually has to be cooked longer than farm-grown livestock, but a lot of prepared products are available, like cured venison. It is essential to keep in mind that when eating cured or smoked meats with bread it should not be accompanied with butter, because it has already enough saturated fatty acids. Wild boar is also a wonderful choice, even though its preparation might be long, but if made in the oven, it occupies no work at all.

In the Mediterranean diet a lot of preparations are composed of long sautéing or oven roasting on a low heat. Grilling should be kept to minimum because of the possible cancerogens that might form when fat is burned on open fire.

Dried fruit and seeds - full of unsaturated fatty acids. A lot of different types of edible seeds, nuts and dried fruit can be found in Latvia. Since the vegetal period is quite short, this sort of snack is great if fresh fruit is not available. Care must be taken with consumption of dried sweet fruit because they are full of sugar.

Non-alcoholic drinks. In the Mediterranean countries a lot of herbal infusions are prepared, especially after dinner to help the digestion. There are a lot of different plants that our great-grandmothers once used to collect every Midsummer 
Night's Eve (Jāņu nakts), such as peppermint, chamomile, nettle, cowslip and many others. Not only helpful after a hearty meal, they can also improve weight control.

Dietary supplements. In cases when not enough micronutrients can be ingested, there is always the possibility for dietary supplements. Many studies have been conducted on resveratrol, lycopene and others, but still we do not have enough evidence for benefits for using dietary supplements. It is always best to take in nutrients with a healthy varied diet, also because nutrients work in synergy.

\section{LATVIAN EATING HABITS}

Latvians are very fond of fatty foods and usually their diet is quite unbalanced. Most people consume boiled sausages that are filled with little meat and many additives. Anything fatty like cheese or meat is consumed on bread with a layer of butter or margarine. The intake of vegetables is quite poor, mostly potatoes with meat or fish dishes, fresh salad with the typical ingredients, like tomato, lettuce and cucumber, all covered with sour cream. Most of the fat and protein consumed are from the animal kingdom. People cook a lot with full fat cream that can be substituted with sauces based on vegetable stock.

Only $49 \%$ of Latvians consider their daily food as wholesome, $39 \%$ found it unhealthy.

Men in general have worse eating habits - low vegetable, whole grain products consumption (Anonymous, 2006).

For a nation living at the sea, it is shocking that only $1 \%$ consumes fish, about 2-4 times per week (Anonymous, 2008). Individuals, who consume fish very often, prefer it smoked which usually contains large amounts of salt.

As mentioned before, Latvia has a lot of small family farms. Unfortunately, the legislation concerning food production is very severe and the subsidies given are not sufficient, making the end product very expensive, if compared to the industrial one. Good quality meat cattle is raised for export only and meat available in the market is of lower quality. White bread at a supermarket does not have less than seven ingredients, when all it needs is water, flour, yeast and salt.

The consumer is not educated enough or willing to read the label to make sure it is healthy. This means that a producer will use any raw material to make production cheaper, since no one is there to protest. We have to keep in mind that, with the production technology, this is the first time in human history that food costs are this low for the way we live. People are willing to choose quantity over quality.

A lot of work should be done on the way supermarkets and markets work to introduce other healthy, local, seasonal products. It is a long process to make an evolution in the market and it is not a one person's job, but still there are products available even now consumed in low quantities that should be revalued.
People should be more educated and more responsible of their diet, intended as eating habits, and lifestyle.

Following the Mediterranean diet for two years has been shown to have a significant decrease in deaths concerning cardiovascular disease by $9 \%$, incidence of cancer by $6 \%$, Parkinson's and Alzheimer's by $13 \%$. This is because a correct diet helps control the perfect weight and improves lipid profile. The risk of diabetes diminishes because of the decrease of sugar metabolism disturbances, and there is an important fall of inflammation and tumour markers (Sofi et al., 2008). Usage of high amounts of extra virgin olive oil decreases the incidence of stroke by $41 \%$ (Anonymous, 2011).

It is not only what you eat that is important in the Mediterranean diet, but everything around it and how the dish came to your table. In Latvia there is a possibility to adapt this kind of lifestyle in a certain way. Old traditions should be brought back to life with the use of forgotten products, cooking and preservation of food. More attention should be brought to education of children in schools, kinder gardens, patients in the doctor's office. Good quality healthy food should be considered as pleasure.

\section{CONCLUSIONS}

Although cardiologists can tell very much about the diet failure of their CVD patients, we need a further nutritionbased research to move us closer to our long-sought goal of developing and implementing dietary strategies that have a major beneficial impact on CVD risk.

A lot of changes should be done in mass production and distribution of food in Latvia, but without a doubt there are products available to have a wholesome diet at any age. The key factor is variety and seasonality.

Education should be done widely to promote tradition and gastronomic heritage as a cultural aspect, as it is thought of in the Mediterranean countries. Healthy lifestyle has to be visible to everyone at any time as a constant reminder of its importance, meaning that teachers have to set an example to children, the doctors to their patients and so on. No credibility of a good diet can come from an obese doctor talking about healthy eating.

If you feel good about your lifestyle yourself, you are more likely to share it with others!

\section{REFERENCES}

Anonymous (2006). Health Compulsory Insurance State Agency. News No. 15. http://www.vmnvd.gov.lv/uploads/files/4fd09434cda66.pdf (last accessed 6 October 2013).

Anonymous (2008). European cardiovascular disease statistics 2008. http://www.bhf.org.uk/publications/view-publication.aspx?ps=1001443 (last accessed 6 October 2013).

Anonymous (2010). Mediterranean diet. UNESCO. http://www.unesco.org/culture/ich/en/RL/00394. 
Anonymous (2011). Medscape Medical News, WebMD.

Appendino, G., Banfi, L. (2011). Molecular diversity and natural products. Mol. Diversity, 15 (2), 291-292.

de Lorgeril, M., Salen, P., Martin, J. L., Monjaud, I., Delaye, J., Mamelle, N. (1999). Mediterranean diet, traditional risk factors, and the rate of cardiovascular complications after myocardial infarction: Final report of the Lyon Diet Heart Study. Circulation, 99 (6), 779-785.

Dumpe, L. (2009). Latviě̌u tautas èdieni. Latvijas vēstures institūta etnogrāfisko ekspedīciju materiāli [Latvian National Cuisine. Materials of Ethnographic Expeditions of the Institute of Latvian History]. Riga: Zinātne. 287 lpp. (in Latvian).

Received 24 September 2012
Erglis, A., Kalvelis. A., Lejnieks, A., Dzerve. V., Latkovskis, G., Mintale, I., Zakke, I., Rasa, I. (2007). CVD Prevention Guidelines. Rīga: Latvijas Kardiologu biedrība.

Fundación Dieta Mediterrịnea. La pirịmide de la Dieta Mediterrịnea se actualiza para adaptarse al estilo de vida actual.

http://dietamediterranea.com/piramide-dietamediterranea/.

McGee, H. (2004). On Food and Cooking: The Science and Lore of the Kitchen. Revised edition. New York: First Scribner. 884 pp. (at pp. 37-38; 555-556)

Pudule, I., Villerusa, A., Grinberga, D., Velika, B., Tilgale, N., Dzērve, V., Rutks, A., Prättälä, R. (2008). Health Behaviour among Latvian Adult Population, 2008, I-III; pp.1-153.

Sofi, F., Cesari, F., Abbate, R., Gensini, G. F., Casini, A. (2008). Adherence to Mediterranean diet and health status: meta-analysis. British Medical Journal, 337, a1344.

\section{VESELĪGAS ALTERNATĪVAS VIDUSJŪRAS DIĒTAI LATVIJĀ}

Slimību profilakses pamatā ir veselīgs dzīvesveids, ko veido regulāra fiziskā aktivitāte un veselīga diēta. L̦oti svarīgi ir balansēt uzṇemto kaloriju daudzumu ar adekvātām fiziskām aktivitātēm. Pēdējo gadu laikā tieši Vidusjūras diēta tiek uzskatīta par visveselīgāko dzīvesveidu sirds un asinsvadu slimību profilaksē. Sekojot Vidusjūras diētai divu gadu garumā, ir novērota mirstības mazināšanās no kardiovaskulārajām saslimšanām par $9 \%$, no vēža par $6 \%$, no Parkinsona un Alcheimera slimībām — par 13\%. Pozitīvie rezultāti ir skaidrojami ar to, ka veselīga diēta palīdz kontrolēt svaru un uzlabot lipīdu profilu. Samazinās arī risks saslimt ar cukura diabētu, jo uzlabojas glikozes vielmaiṇa. Ievērojami samazinās iekaisuma un audzēja markiieri. Vidusjūras diētu definē produktu grupas: auksti spiesta olīvellıa - svarīgs mononepiesātināto taukskābju avots; daudz aug̣̣u un dārzeṇu; pilngraudu produkti, pākšaugi, rieksti un sēklas; pazemināta tauku satura piena produkti (bez pievienotiem augu taukiem); zivis (vismaz divas reizes nedēlāa); putnu gaḷa, liellopa gal̦a un cūkgaḷa nelielos daudzumos; olas — 0-4 nedēḷā. Šāda veida uzturu ir iespējams pielāgot arī ziemeḷvalstīs, atrodot produktus ar līdzīgu uzturvērtību. L,oti svarīgi ir pievērst uzmanību svaigo produktu sezonalitātei. Tā kā Latvijā ir ḷoti īss veǵetatīvais periods, nepieciešams ir uzlabot konservēšanas un uzglabāšanas metodes ziemas mēnešiem. Ziemeḷos ir pieejama liela graudaugu un pākšaugu izvēle. Jāpievērš lielāka uzmanība piena produktu kvalitātei un jāveicina zemnieku ražoto produktu patērin̄š, kā arī jāsamazina rūpnieciski ražotu produktu patēriņšs. Gaḷas produktu īpatsvars diētā būtu jāsamazina līdz trīs reizēm nedēḷā, dodot priekšroku meža dzīvnieku gaḷai, kas ir bagāta ar nepiesātinātām taukskābēm un dzelzi, bet tajā ir zemāks piesātināto tauku saturs. Latvijā diemžēl netiek ražotas augstas kvalitātes augu ellıas. Auksti spiestas olīveḷlas (extra virgin) uzturvielas ir grūti salīdzināmas un aizvietojamas ar citām, tās ievērojami spēj uzlabot kardiovaskulāro veselību. Augsts šīs olīveḷlas patēriņš spēj samazināt insulta risku līdz pat $41 \%$. 